\title{
Occipital Encephalocele: A Case Report and Literature Review
}

Nadia Ch'michi ${ }^{1 *}$, Mariyam Benayada ${ }^{1}$, Nada Douraidi ${ }^{1}$, Maimouna Bouh ${ }^{1}$, Oumaima Sarhdaoui ${ }^{1}$, Hounaida Mahfoud ${ }^{1}$, Najia Zeraidi' ${ }^{2}$ Ibrahim Rhrab ${ }^{2}$, Amina Lakhdar ${ }^{2}$, Aziz Baidada ${ }^{3}$, Aicha Kharbach ${ }^{3}$

${ }^{1}$ Resident Doctor, Department of Obstetrics Gynecology, Maternity Souissi, University Hospital Center IBN SINA, University Mohammed V, Rabat, Morocco

${ }^{2}$ Professor, Department of Obstetrics Gynecology, Maternity Souissi, University Hospital Center IBN SINA, University Mohammed V, Rabat, Morocco

${ }^{3}$ Professor, Department of Obstetrics Gynecology and Head of Service Obstetrics Gynecology Service Maternity Souissi Chis Rabat, Maternity Souissi, University Hospital Center IBN SINA, University Mohammed V, Rabat, Morocco

DOI: $\underline{10.36347 / \text { sjams.2020.v08i12.007 }}$

| Received: 09.11.2020 | Accepted: 20.11.2020 | Published: 10.12 .2020

*Corresponding author: Nadia Ch'michi

Abstract

An encephalocele is defined as the protrusion of brain tissue and / or meninges out of the skull through a congenital gap in the skull. It can be isolated or part of a polymalformative context, such as MECKEL syndrome. Thanks to the ultrasound a prenatal diagnosis can be made and reveals a cranial defect with a cerebral hernia of varying degrees, either the hernia is purely cystic or may contain echoes from brain tissue. The treatment of encephalocele is surgical, it consists of a resection of the dysplastic brain tissue, a systematic coagulation of the choroid plexus within the malformation, and in some cases a preservation without pressure of the healthy looking nervous tissue. The prognosis depend mainly on the size of the herniated brain parenchyma and the associated malformations. At the end of this observation we will focus on the occipital encephalocele, the prenatal diagnosis as well as its management.

Keywords: Occipital encephalocele, malformation, pregnancy.

Copyright $(\mathcal{C} 2020$ The Author(s): This is an open-access article distributed under the terms of the Creative Commons Attribution 4.0 International License (CC BY-NC 4.0) which permits unrestricted use, distribution, and reproduction in any medium for non-commercial use provided the original author and source are credited.

\section{INTRODUCTION}

The occipital encephalocele is a herniation of nervous tissue and / or meninges through a congenital occipital bone gap, in connection with a defect in the closure of the cranial part of the neural tube. Either its a meningocele, encephalocele or meningoencephalocele [1].

The encephalocele is a rare birth defect, caused by a neural tube closure abnormality that occurred a few weeks after conception. Usually there is no well-defined genetic cause and no significant risk of recurrence. The consequences for the fetus can be severe, even serious, with an unviable newborn at birth [2].

The objective of our work is to study the modalities of the diagnosis and management of an occipital encephalocele in a case in the gynecological and obstetrical department the Souissi maternity hospital Rabat.

\section{Case Report}

Mrs FD, 36 year old female patient, gravida 4, para 4, 3 vaginal deliveries, admitted in our departement for delivery of her current pregnancy, which estimated at 38 weeks and 4 days. There was no other significant past, obstetric, or surgical history.

On examination, the patient was clinically stable with active uterine contractions, an excessive uterine height $(36 \mathrm{~cm})$, an active fetal heart beat, vaginal examination revealed a flexible median cervix, well erased and dilated with 2 fingers, cephalic presentation and intact membrane. On ultrasound the fetus presents a mass on the midline of the skull protruding in the occipital region making $110 * 150 \mathrm{~mm}$ correspond to an occipital encephalocele. The indication of a cesarean delivery was made, giving birth to a live born male of 4300g grams and Apgar score 9-10 at first and fifth minutes, respectively. Presenting an enormous occipital encephalocele (Figures), the newborn was entrusted to the pediatric surgery department for possible care. 
The patient's consent and the institutional ethical board's permission were taken for the
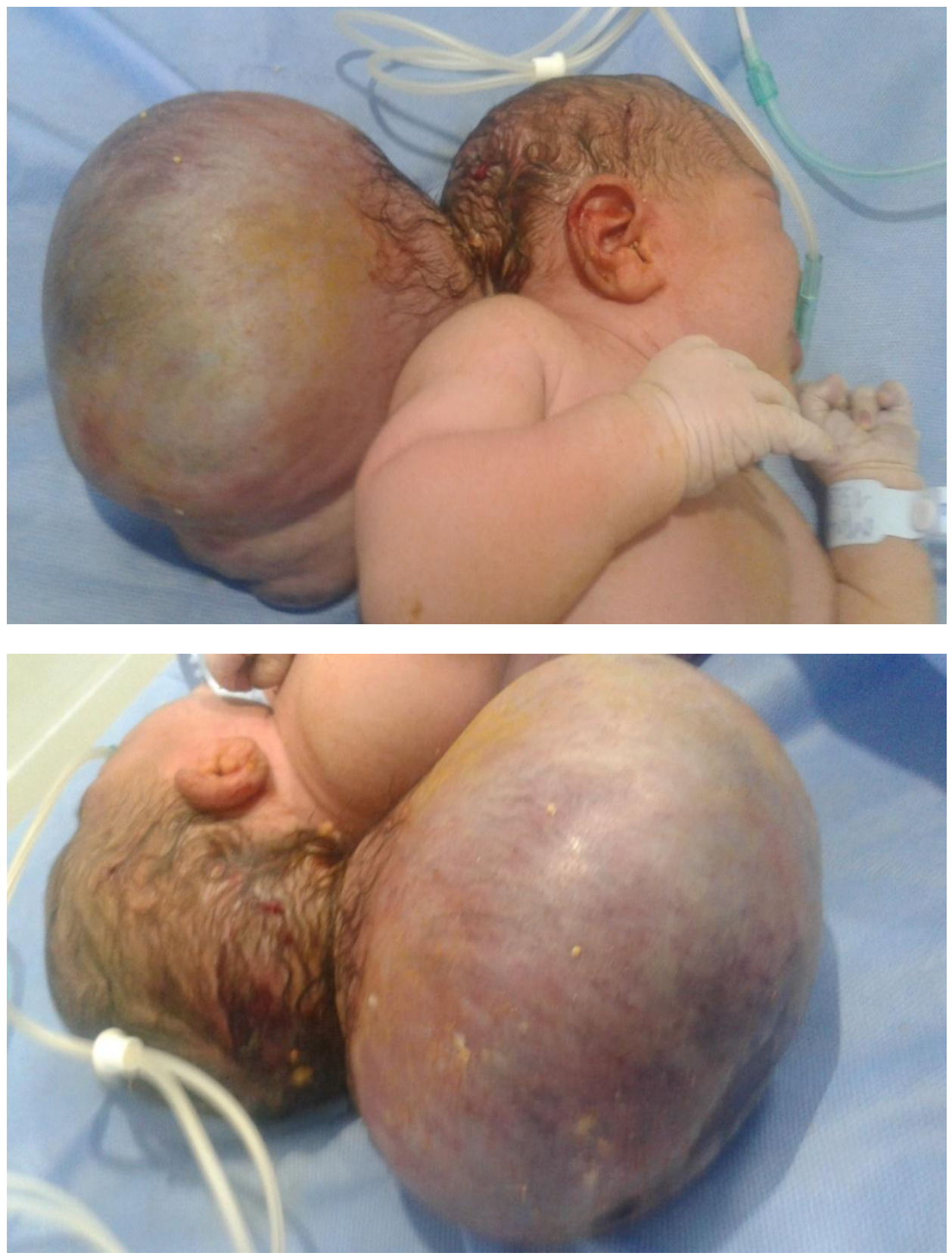

\section{DISCUSSION}

The incidence of encephalocele is 0.8 to 3.0 per 10,000 births [1]. Studies showed that several factors have been implicated in the occurrence of neural tube defects, therefore encephalocele is generally considered to be a multifactor abnormality, resulting from the interaction of various factors, especially genetic and environmental [3]. According to Lemire cited by Robert L [4], these factors act for certain malformations during neurilation, between the first 30 days of gestation and the closure of the posterior neuropore, and for others during the post-neurilation period [5, 6]. A prospective study of 161 occipital encephaloceles carried out in the Niamey National
Hospital in Niger between January 1999 and March 2008 , consanguinity was found in $67.08 \%$ of cases [7]. Also, young maternal age and multiparity are associated to neural tube defects [8].

There are many classification systems for encephaloceles. The first and most used classification, is Suwanwela classification, described in 1972, which divides encephaloceles according to location and distinguishes five groups $[3,9,10]$ :

\section{Posterior Meningoencephaloceles}

They are located in the occipital region, and are often very large. This is the entity our case fits into. The occipital location of the encephalocele is the most 
common in the literature and represents an important prognostic factor [1].

The meningoencephaloceles of the vault

They are subdivided into:

- Interfrontal

- Anterior fontanel

- Interparietals

- Posterior fontanel

- Temporal

Frontoethmoidal meningoencephaloceles They share:

- Naso-frontal

- Naso-ethmoidal

- Naso-orbital

Basal meningoencephaloceles:

- Transethmoidal

- Sphenoethmoidal

- Trans-sphenoidal

- Spheno-orbital

\section{Cranioschisis}

Antenatal ultrasound is the imaging of choice in antenatal screening for brain malformations, the diagnosis of occipital encephalocele is based on the detection of a head defect with a herniated brain of varying degrees. The classic ultrasound appearance correspond to a mass in the midline of the skull, which occurs in the occipital regions. The mass may be purely cystic or it may contain echoes from brain tissue [11]. Other examinations may be ordered as a second line such as: fetal MRI and AFP testing; MRI finds its interest especially in postnatal to define the content of an encephalocele before a surgical intervention, it allows to better identify the extent of the brain tissue in an encephalocele and to define the intracranial connections to facilitate surgical planning and better assess the prognosis.

The encephalocele can appear in isolation or be associated with other malformations such as hydrocephalus, agenesis of the corpus callosum, Arnold Chiari malformation, microcephaly, craniosynostosis [12]. Encephaloceles can also be integrated into a polymalformative context found in certain malformation syndromes or certain genetic diseases. There is a whole series of known syndromes which may include an encephalocele such as MECKEL syndrome, WARBURG syndrome, Amniotic strings syndrome, and KNOBLOCH syndrome [3].

The question of the mode of delivery to adopt in the case of a fetus affected by an encephalocele in cephalic presentation remains controversial. It is evident that the size of the encephalocele is a determining factor and that a cesarean was a safer method of delivery [13].
The differential diagnosis is generally easy and easily eliminated [14]:

- A cephalhematoma.

- A lipoma.

- A dermoid cyst of the midline.

- A cystic hygroma (TURNER's cervical hygroma or other lymphedemas.

- A teratoma

The management is surgical, it is a restorative surgery; there is most often no emergency to intervene, but it is better not to wait for the lesion to grow, and also poses problems of bone reconstruction when they are operated late. In extreme cases when the encephalocele is very large, surgery may be more urgent [2].

Surgery involves resection of dysplastic brain tissue, systematic coagulation of the choroid plexus within the malformation, and in some cases pressurefree preservation of healthy looking nerve tissue [1].

The prognosis and course depend mainly on the size of the herniated brain parenchyma and the associated malformations. An isolated encephalocele has a better prognosis [12]. Poor epidermization and the presence of nervous tissue in the malformation are factors of poor prognosis [1].

Mortality varies between 20 and $36 \%$ for a follow-up between 1 month and 20 years $[15,16]$. According to the study by Sanoussi et al., the 3-month mortality rate was $22.36 \%$. The factors of mortality were: pure encephalocele, a size greater than or equal to the head circumference, association with hydrocephalus and when the age of the newborn is less than 15 days [1]. Morbidity is significant in the literature. Thus in the LO series [17], the long-term evolution of psychomotor retardation was presented as follows: normal in $48 \%$ of cases, average retardation in $11 \%$ of cases, moderate in $16 \%$ of cases and severe in $25 \%$ cases.

Prevention of encephalocele and neural tube defects in general is done by taking folic acid during the preconception period. In developed countries, neural tube defects are rare largely due to preventive measures. In a multicenter study (11 centers) evaluating the preventive intake of folic acid between 1987 and 1996 Rosano et al., [18] report that there is a significant decrease in the prevalence of neural tube defects in centers such as those in Atlanta, England, Wales, Hungary or Japan. However, there was no positive effect in Latin American countries. The authors explain this disproportion by the lack of pregnancy planning in $50 \%$ of cases and by the poor folic acid diet [1]

\section{CONCLUSION}

The occipital encephalocele is a rare malformation. The diagnosis is usually made antenatal 
by ultrasound. The treatment is surgical and the prognosis depends on the size and the associated malformations.

\section{DeClaRATIONS}

Guarantor of Submission: The corresponding author is the guarantor of submission.

\section{Acknowledgements: None.}

Funding: There are no funding sources to be declared.

Availability of data and materials: Supporting material is available if further analysis is needed.

Competing interests: The authors declare that they have no competing interests.

\section{REFERENCES}

1. Sanoussi S, Chaibou M, Bawa M, Kelani A, Rabiou M. Encéphalocèle occipitale: aspects épidémiologiques, cliniques et thérapeutiques: à propos de 161 cas opérés en 9 ans à l'hôpital national de niamey. African Journal of Neurological Sciences. 2009;28(1).

2. l'encéphalocèle occipitale, neurochirurgie pédiatrique de Lille.

3. KHABBACH OUAFA L'ENCEPHALOCELE OCCIPITALE (Etude rétrospective à propos de 5 cas) THESE PRESENTEE ET SOUTENUE PUBLIQUEMENT LE 07/03/2011 faculté de médecine et de pharmacie de Fes Maroco.

4. Sanoussi S, Gamatié Y, Kelani A, Sbai C, Abarchi H, Bazira L. Les malformations du tube neural au Niger: plaidoyer pour le traitement préventif par l'acide folique en période périconceptionnelle. Medecine Afrique Noire. déc 2001; tome 48-N 12: 509-515.

5. Rosano A, Smithells D, Cacciani L, Botting B, Castilla E, Cornel M, Erickson D, Goujard J, Irgen L, Merlob P, Robert E, Siffel C, Stollc, Sumiyoshi $\mathrm{Y}$. Time trends in neural tube defects prevalence in relation to preventive strategies: an international study. J Epidemiol Community Health. 1999; 53(10):630-5.

6. Owen TJ, Halliday JL, Stone CA. Neural tube defects in Victoria, Australia: potential contributing factors and public health implications. Aust NZ J Public Health. 2000;24(6):584-9.
7. Archer NP, Langlois PH, Suarez L, Brender J, Shanmugam R. Association of paternal age with prevalence of selected birth defects. Birth Defects Res A Clin Mol Teratol. 2007; 79(1): 27-34.

8. Mohanty A, Biswas A, Reddy M, Kolluri S. Expansive cranioplasty for massive occipital encephalocele. Childs Nerv Syst. 2006;22(9):1170-6.

9. Pernot PH, Gueye M, Massoni F, Ducolombier A. Les céphalocèles. Résultats thérapeutiques à propos d'une série de 63 cas. Médecine et armées, 1986; 14(7):559-563.

10. Rahmaoui A. Les encéphalocèles (étude retrospective de 31 cas). Thèse Méd ; faculté de médecine et de pharmacie de Casablanca; 1991; 14.

11. El Mhabrech H, Mansour SB, Dakkem M, Zrig A, Hmida HB, Hafsa C. Diagnostic anténatal de l'encéphalocèle. Journal of Neuroradiology. 2016 Mar 1;43(2):105-6.

12. Messaoud MB, Khalfaoui S, Darmoul M, Kilani M, Hattab MN. Encéphalocèle occipitale à propos de 20 cas. Neurochirurgie. 2018 Jun 1;64(3):270.

13. Wilson RD, Audibert F, Brock JA, Campagnolo C, Carroll J, Cartier L, Chitayat D, Gagnon A, Johnson JA, Langlois S, MacDonald WK. Anomalies fœtales affectant le tube neural: Dépistage/diagnostic prénatal et prise en charge de la grossesse. Journal of Obstetrics and Gynaecology Canada. 2014 Oct 1;36(10):940-2.

14. Raghu SR, Shubha AM, Das K. Mature occipital teratoma in a neonate. International Journal of Pediatric Otorhinolaryngology Extra. 2009.

15. Kotil K, Kilinc B, Bilge T. Diagnosis and management of large occipitocervical cephaloceles: a 10-year experience. Pediatr Neurosurg. 2008; 44(3):193-8.

16. Martínez-Lage JF, Poza M, Sola J, Soler CL, Montalvo CG, Domingo R, Puche A, Ramón FH, Azorín PL. The child with a cephalocele: etiology, neuroimaging, and outcome. Childs Nerv Syst. 1996; 12(9):540-50.

17. Lo BW, Kulkarni AV, Rutka JT, Jea A, Drake JM, Lamberti-Pasculli M, Dirks PB, Thabane L. Clinical predictors of developmental outcome in patients with cephaloceles. J Neurosurg Pediatrics. 2008; 2(4):254-7

18. Raja RA, QureshI AA, Memon AR, Ali H, Dev V. Pattern of encephaloceles: a case series. J Ayub Med Coll Abbottabad. 2008; 20(1):125-8. 